\title{
Experimental Localization of Muscarinic Receptor Subtypes to Cingulate Cortical Afferents and Neurons
}

\author{
Brent A. Vogt and David L. Burns \\ Departments of Anatomy and Physiology, Boston University School of Medicine, Boston, Massachusetts 02118, and \\ Veterans Administration Hospital, Bedford, Massachusetts 01730
}

\begin{abstract}
A technique was developed to evaluate the potency of ligand binding at $M_{2} A C h$ receptors and to experimentally localize the $M_{1}$ and $M_{2}$ subtypes to specific neuronal processes. Normal and experimental material was prepared with tritiated ligand binding to cryostat-sectioned area 29c of posterior cingulate cortex in rat, coverslip autoradiography, and single-grain-counting techniques. Three fundamental issues were addressed.
\end{abstract}

1. A morphological criterion termed an index of heterogeneity was developed by which the specificity of $M_{2}$ binding by different ligands could be assessed. The index was calculated by first determining the laminar distribution of pirenzepine (PZ) binding sites and then summing absolute laminar variations from this distribution for each ligand. According to this measure the most efficient protocol for assaying $M_{2}$ sites was tritiated oxotremorine- $M$ (OXO) coincubated in unlabeled $P Z\left(5 \times 10^{-8} \mathrm{M}\right)$. The classical muscarinic antagonist propylbenzilylcholine mustard (Pr$B C M)$, however, when coincubated in $P Z$, was almost as efficient as PZ-blocked OXO binding.

2. Terminal axons of neurons in the anterior thalamic nuclei (ATN) have $M_{2}$ receptors based on the following observations. First, specific binding of the $M_{1}$ ligand $P Z$ was unaffected by ATN lesions. Second, tritiated OXO and PrBCM binding blocked with unlabeled $P Z$, conditions favoring $\mathbf{M}_{\mathbf{z}}$ receptor binding, showed significant reductions in binding in layers la, Ib, and IV following ATN ablations. Third, $I_{50}$ values as determined by competition of PZ for PrBCM binding sites were shifted to lower concentrations in superficial layers by ATN lesions but not in deep layers where the thalamus does not terminate. Finally, in contrast to PZ-blocked OXO and PrBCM binding, binding of PZ-blocked ${ }^{3} \mathrm{H}$-quinuclidinyl benzilate (QNB) was reduced to homogeneity following ATN lesions.

3. Cortical pyramidal neurons have dendritic receptors that are primarily of the $M_{1}$ subtype but may also include $M_{2}$ sites. Thus, full depth ibotenic acid lesions reduced $P Z$ binding by almost $70 \%$. Neurotoxin lesions of neurons in layers II-IV or $\mathrm{Vb}-\mathrm{VI}$ were followed by degeneration of the apical dendrites of pyramids in layer $I$ and 78 and $15 \%$ reductions, respec-

\footnotetext{
Received Apr. 13, 1987; revised Aug. 13, 1987; accepted Aug. 21, 1987.

We thank Drs. Ladislav Volicer, Enzio Muller, and Ellen Townes-Anderson for reading and commenting on the manuscript. This research was supported by NIH Grant NS 18745 .

Correspondence should be addressed to Brent A. Vogt, Departments of Anatomy and Physiology, Boston University School of Medicine, 80 E. Concord Street, Boston, MA 02118.

Copyright $(C) 1988$ Society for Neuroscience $0270-6474 / 88 / 020643-10 \$ 02.00 / 0$
}

tively, in PZ binding. Also, full-depth neurotoxin lesions combined with ATN ablations completely abolished heterogeneities in PrBCM and PZ-blocked OXO binding.

These data demonstrate that experimental techniques can be used in conjunction with normal material to make morphological assessments of the efficiency of binding of putative $M_{2}$ ligands. This study also demonstrates that $M_{2}$ receptors are located on noncholinergic thalamic axon terminals and the dendrites of cortical neurons, while $M_{1}$ receptors are mainly dendritic in location. Reduced binding of $P Z$ in layer I following laminar neurotoxin lesions supports the proposition that $M_{1}$ sites are on apical dendritic tufts of pyramidal neurons. Finally, QNB appears to differentiate between $M_{2}$ receptors on ATN axons, which it labels, and those on apical dendrites, which it does not label.

Two muscarinic ACh receptors have been characterized primarily on the basis of agonist binding properties (Birdsall et al., 1978; Wamsley et al., 1980; Hammer and Giachetti, 1982; Potter et al., 1984). The nonclassical antagonist pirenzepine (PZ) binds with a higher affinity to the $M_{1}$ than the $M_{2}$ site (Hammer et al., 1980; Watson et al., 1983; Wamsley et al., 1984), and regional analyses of $\mathrm{PZ}$ binding suggest that it binds to a subpopulation of sites recognized by classical antagonists such as quinuclidinyl benzilate (QNB) (Watson et al., 1983; Yamamura et al., 1983; Wamsley et al., 1984; Watson et al., 1986). In contrast, the muscarinic receptor agonist oxotremorine-M (OXO) binds with a higher affinity to $M_{2}$ than $M_{1}$ sites and can be used to identify $\mathrm{M}_{2}$ sites in homogenized or cryomicrotome-sectioned tissue (Birdsall et al., 1980; Birdsall and Hulme, 1983; Spencer et al., 1986). Another approach to identifying $M_{2}$ sites is to block the $M_{1}$ component of classical antagonist binding with $\mathrm{PZ} \mathrm{(Lu-}$ thin and Wolfe, 1984; Potter et al., 1984; Palacios et al., 1986). As yet there are no criteria by which to directly assess strategies for localizing $\mathrm{M}_{2}$ sites in cryomicrotome sections.

Although there is no direct morphological evidence for the cellular localization of $\mathbf{M}_{1}$ or $\mathbf{M}_{2}$ sites, electrophysiological and biochemical studies are suggestive. Thus, $\mathbf{M}_{1}$, or $\mathbf{P Z}$-sensitive, sites may be postsynaptic on pyramidal neurons, since PZ blocks ACh-evoked depolarizations (McCormick and Prince, 1985, 1986). Furthermore, there is biochemical support for presynaptic localization of $\mathrm{M}_{2}$ sites on cholinergic (Ganguly and Das, 1979; Nordstrom and Bartfai, 1980; Zarbin et al., 1982; Raiteri et al., 1984; Mash et al., 1985) and dopaminergic (De Belleroche et al., 1982; Raiteri et al., 1984) axons.

The laminar and nuclear distributions of $M_{1}$ and $M_{2}$ sites have been analyzed (Yamamura ct al., 1983; Pottcr et al., 1984; 
Wamsley et al., 1984; Palacios et al., 1986; Spencer et al., 1986; Watson et al., 1986); however, these studies cannot determine the location of muscarinic receptors on specific neurons and/or afferent axons. Although cells can be dissociated and specific binding determined autoradiographically for identified types of adult neurons (Vogt et al., 1987), there are limitations to this approach. First, the only ligands appropriate for wet emulsion autoradiography are those that are irreversible, but propylbenzilylcholine mustard (PrBCM), which is irreversible, is not selective for a receptor subtype. Since $\mathrm{PZ}$ is reversible, this ligand of choice for the $M_{1}$ receptor is not suitable for assaying receptors on dissociated neurons. Second, extensive pruning of the dendritic and axonal trees occurs during dissociation. Thus, spines, entire apical tufts, and the axonal arbors are removed. Third, this approach cannot be used to address localization to afferent axons since the identity of axonal processes are lost following dissociation.

An experimental approach to receptor subtype localization that overcomes the shortcomings of the dissociation technique is the placement of restricted lesions and evaluation of subsequent alterations in binding. Pivotal to developing these studies are heterogeneities in the distribution of dendrites and afferent terminations as well as receptor subtype distribution. Matches in these heterogeneities serve as the basis for lesion placement. Ablation specificity determines, in part, the resolution of this technique. In the present study, for example, neurotoxin lesions of only a few layers allow for assessing receptor subtypes on apical dendritic tufts.

The present study used laminar heterogeneities in the distribution of afferent axons, dendrites, and receptor subtypes to develop methods for comparing the binding of various ligands to the $\mathrm{M}_{2}$ receptor. Optimal protocols were used following single or multiple ablations to localize muscarinic receptor subtypes in cingulate cortex. Of particular note is the use of laminar neurotoxin lesions for the study of $\mathrm{PZ}$ binding to pyramidal cell apical dendritic tufts.

\section{Materials and Methods}

Thalamic and cortical ablations were made as previously reported (Vogt, $1984)$ in 96 hooded, Long-Evans male rats (300-350 gm). Laminar lesions were made by either injecting small amounts of ibotenic acid into deep cortical layers with a $5 \mu$ l Hamilton syringe $(0.05 \mu$ l injections of $10 \mu \mathrm{g}$ ibotenic acid dissolved in $1 \mu \mathrm{l}$ of physiological saline) or by making very large injections in one hemisphere (3 injections of $0.3 \mu \mathrm{l}$ each) and analyzing receptor binding in the contralateral hemisphere. In the latter condition, limited release of the neurotoxin from the heavily injected hemisphere resulted in destruction of neurons in the superficial layers of contralateral cortex. As each of these injection procedures could not be rigorously controlled, numerous cases were prepared for an experiment (i.e., 6-10) and screened histologically before receptor site analysis was undertaken. Following a 2 week postoperative survival period, animals were sacrificed with $\mathrm{CO}_{2}$ and intracardially perfused with $50-100 \mathrm{ml} \mathrm{cool}\left(15^{\circ} \mathrm{C}\right) \mathrm{Krebs}-\mathrm{Henseleit}$ buffer. The brains were removed and frozen to $-70^{\circ} \mathrm{C}$ in hexane. Cryostat microtome sections were cut at a $16 \mu \mathrm{m}$ thickness and mounted on subbed slides. A total of 4600 slides with 2 or 3 sections per slide were prepared and analyzed for these studies.

Unlabeled PZ was kindly provided by Boehringer Ingelheim, Ltd., while tritiated ligands, including PrBCM (specific activity, $43 \mathrm{Ci} / \mathrm{mm}$ ), $\mathrm{PZ}$ (specific activity, $84 \mathrm{Ci} / \mathrm{mm}$ ), OXO (specific activity, $84.9 \mathrm{Ci} / \mathrm{mm}$ ), and QNB (specific activity, $41.8 \mathrm{Ci} / \mathrm{mm}$ ), were obtained from New England Nuclear. The in vitro protocol for the assay of PrBCM binding was similar to that employed by Rotter et al. (1979). The assay for PZ binding was modified from Yamamura et al. (1983) and Wamsley et al. (1984) and included a preincubation in Krebs-Henseleit (30 min, room temperature), a $70 \mathrm{~min}$ incubation in $\mathrm{PZ}\left(15 \mathrm{nM}, 24^{\circ} \mathrm{C}\right), 2$ washes in Krebs-Hensclcit $\left(2 \mathrm{~min}\right.$ cach, $5^{\circ} \mathrm{C}$ ), and rapid air drying. For the $\mathrm{OXO}$ and QNB assays, there was a $25 \mathrm{~min}$ preincubation in $20 \mathrm{~mm}$ HEPESTris buffer including $10 \mathrm{mM} \mathrm{Mg}^{+2}$ at $\mathrm{pH} 7.5$ and $23^{\circ} \mathrm{C}$. Sections were incubated at the same temperature in either 10 or $0.1 \mathrm{~nm}$ OXO for 30 min or in $1 \mathrm{nM}$ QNB for $120 \mathrm{~min}$. Throughout this study the abbreviation $O X O$ refers to the $10 \mathrm{nM}$ concentration unless otherwise noted. Binding was terminated with two 2 min washes in cold $\left(3^{\circ} \mathrm{C}\right)$ buffer followed by one $2 \mathrm{~min}$ wash in cold water and rapid air drying. Nonspecific binding was evaluated for all ligands by parallel incubation of a series of sections in radioactive ligand in the presence of $10^{-6} \mathrm{M}$ atropine.

Two different autoradiographic techniques were used. For PrBCM the sections were dipped into Kodak NTB-2 emulsion, exposed for 3 weeks, developed in Kodak D-19 $\left(6^{\circ} \mathrm{C}\right)$ and fixed with Kodak Rapid Fix without hardener. For the $\mathrm{PZ}, \mathrm{OXO}$, and QNB assays sections were apposed to coverslips coated with dried emulsion according to the technique of Young and Kuhar (1979), exposed and developed as already noted for PrBCM. All sections were counterstained with thionin, but, since the PrBCM protocol includes a light prefixation step, morphological preservation and cytoarchitecture in this series was superior to that of the other series

A computerized image-analysis system was used to count grain densities and determine specific binding. Readings per $2500 \mu \mathrm{m}^{2}$ of a cortical layer were taken for total and atropine-blocked binding, visually corrected for miscounts due to overlapping grains and then subtracted to determine specific binding. Specific binding in 8 sublaminae in normal, unoperated cortices contralateral to ablated hemispheres and cortices from ablated hemispheres were determined in 2 or 3 sections per brain and means \pm SE calculated. Although binding in unoperated hemispheres of ATN ablated cases was similar to that of normal cases, ibotenic acid often spread to contralateral cortex, and so these cases were compared to unoperated controls processed exactly the same way. Differences between means were evaluated with $t$ tests $(p \leq 0.05)$.

Two issues are particularly important for interpretation of experimental localization findings. First, do lesions produce reductions in receptor density or affinity? A number of studies report that ablation and ligation techniques do not significantly alter muscarinic receptor affinity, but rather reduce receptor density (Briggs et al., 1981; Kamiya et al., 1981; Zarbin et al., 1982; Andree et al., 1983; Mash et al., 1985). Neither is affinity affected by dissociation procedures (James and Klein, 1982). In the present study, ablation-induced reductions in ligand binding to muscarinic receptors are consistent with a loss of receptors on axons or dendrites. Second, does transneuronal degeneration account for alterations subsequent to deafferentation lesions (Hattori and Fibiger, 1982)? As noted previously (Vogt, 1984), 2 peaks in PrBCM binding in cingulate cortex were reduced by $40-50 \%$ following ATN or undercut lesions, and they remained after ibotenic acid lesions. We have explored ibotenic acid-ablated cortex electron microscopically and found that, although neurons are virtually nonexistent, axon terminals did remain (unpublished observations). This confirms the observation of Schwarcz et al. (1979) that afferent axons remain intact in neurotoxin preparations. Thus, it is unlikely that reductions in receptor binding following ATN lesions are the result of transneuronal degeneration.

\section{Results}

\section{Ligand specificity for the $M_{2}$ receptor subtype}

Normal laminar binding profiles. PZ binding was essentially homogeneous, although binding was lowest in layer Ia and highest in layers Ic and II-III. Figure 1 presents the laminar binding profiles for $\mathrm{PZ}, \mathrm{PrBCM}, \mathrm{QNB}$, and $\mathrm{OXO}$. The specific binding by layer is expressed as a percentage of all specific binding for all layers because absolute numbers derived from different experiments and using different autoradiographic techniques are not comparable.

Ligands that bound to both $\mathrm{M}_{1}$ and $\mathrm{M}_{2}$ receptor subtypes such as PrBCM and OXO showed a marked heterogeneity in their laminar binding profiles, while the heterogeneity in QNB binding was not as pronounced. These heterogeneities were the reverse of $P Z$ binding in that they tended to be highest in layers Ia and IV, where PZ binding was low.

Index of heterogeneity. Since the laminar distribution of $\mathrm{PZ}$ binding was essentially homogeneous and that of compounds 


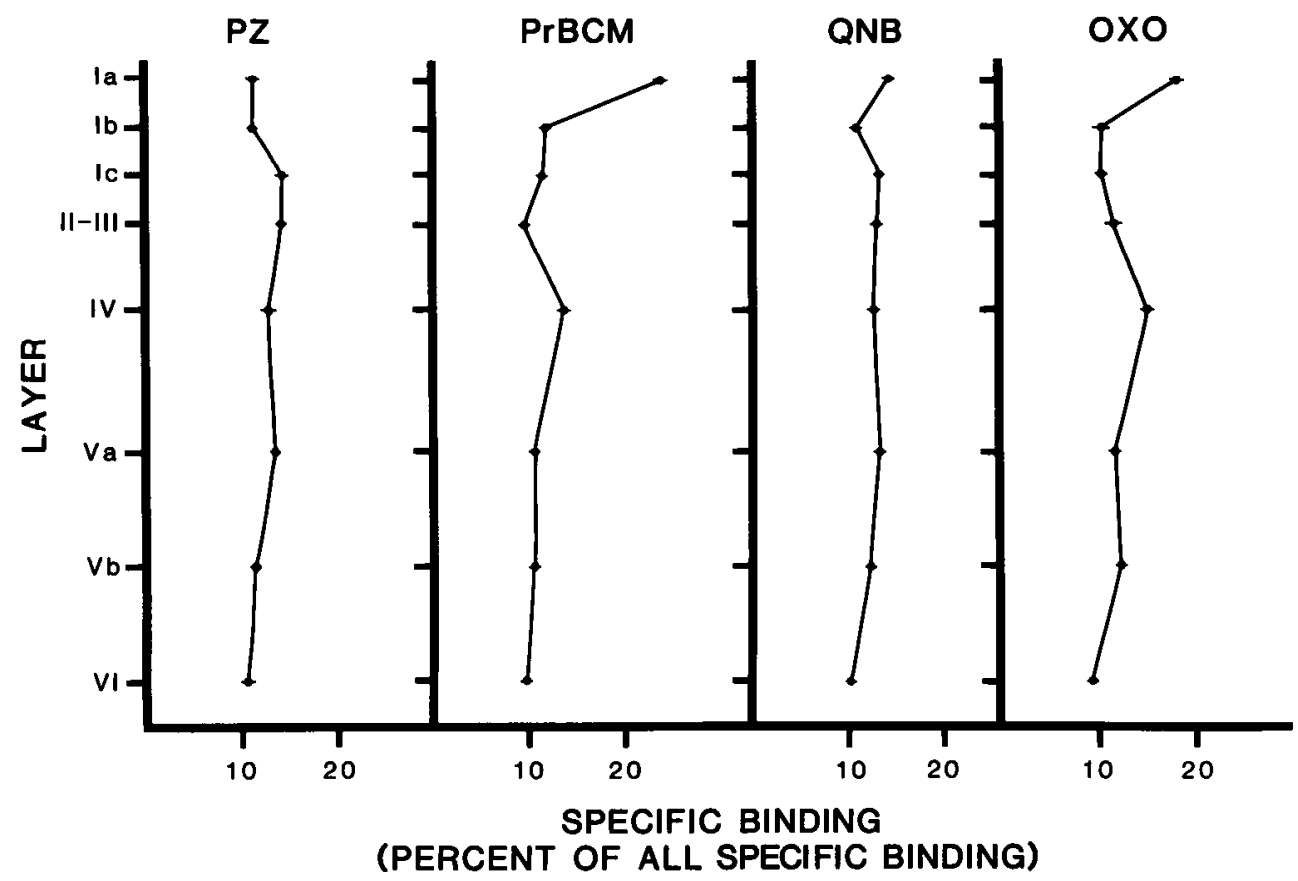

Figure 1. Laminar distribution of the binding of 4 tritiated ligands in area $29 \mathrm{c}$. Binding in each layer (mean $\pm \mathrm{SE}$ ) is presented as a percentage of that for all layers. which bound to both muscarinic receptors was heterogeneous, the greatest deviations from homogeneity reflected most efficient $\mathrm{M}_{2}$ binding, i.e., least concomitant $\mathrm{M}_{1}$ binding. A heterogeneity index was calculated by first determining the relative binding of each ligand by layer. Next, deviations from PZ binding were calculated for each ligand and the absolute values summed to determine the magnitude of variation as shown in Table 1(A). These summed values were the index of heterogeneity.

Since the validity of the index was particularly dependent on the relative distribution of $P Z$ binding, and index of heterogeneity was calculated for $\mathrm{PZ}$ itself from an entirely different experiment. The index of 3.8 demonstrated that there was virtually no difference in the laminar distribution of $\mathrm{PZ}$ binding, even though the total number of grains in one experiment was almost 2.5 times greater than in the other.

Theoretically, variations in binding from $12.5 \%$ in each layer (i.e., $100 \% / 8$ layers $=12.5 \%$ ) could have been used as a measure of absolute homogeneity instead of PZ binding. However, by using specific PZ binding, tissue artifacts such as differential laminar quenching of the tritium signal were standardized. In addition, there was no a priori reason to believe that $\mathbf{M}_{1}$ receptor binding was absolutely homogeneous.

A number of interesting points can be made from Table 1(A). First, 10 nm OXO had a lower index of heterogeneity than did PrBCM. Second, a low concentration of OXO (0.1 nM) had a higher index than did the $10 \mathrm{~nm}$ concentration. Third, blocking the $M_{1}$ component of classical antagonist binding with $5 \times 10^{-8}$

Table 1. Measures of efficiency of $M_{2}$ binding

A. Index of heterogeneity

\begin{tabular}{|c|c|c|c|c|c|c|c|c|}
\hline Layer & $\mathrm{PZ}^{a}$ & PrBCM & $\begin{array}{l}\text { PrBCM/ } \\
\text { PZ }\end{array}$ & $\begin{array}{l}\text { OXO, } \\
10 \mathrm{~nm}\end{array}$ & $\mathrm{OXO} / \mathrm{PZ}$ & $\begin{array}{l}\text { OXO, } \\
0.1 \mathrm{nM} \\
\end{array}$ & QNB & $\begin{array}{l}\text { QNB/ } \\
\mathrm{PZ}\end{array}$ \\
\hline Ia & 11.2 & 12.1 & 12.2 & 7.1 & 12.5 & 9.0 & 2.9 & 6.6 \\
\hline Ib & 11.2 & 0.5 & 1.7 & -0.6 & 0 & -0.8 & -0.3 & -1.2 \\
\hline Ic & 14.4 & 3.1 & -4.4 & -3.9 & -5.0 & -4.4 & -1.3 & -2.8 \\
\hline II-III & 14.2 & -4.7 & -3.7 & -2.3 & -2.6 & -1.5 & -1.2 & -0.2 \\
\hline IV & 12.9 & 0.8 & 0.5 & 2.3 & 2.2 & 2.9 & 0 & 2.1 \\
\hline $\mathrm{Va}$ & 13.6 & -3.1 & -3.6 & -1.8 & -2.7 & -2.1 & -0.4 & -1.6 \\
\hline $\mathrm{Vb}$ & 11.7 & -1.2 & -1.2 & 0.6 & -1.0 & -0.2 & 0.7 & 0.1 \\
\hline VI & 10.8 & -1.0 & -1.7 & -1.3 & -3.2 & -2.9 & -0.4 & -2.9 \\
\hline Index & - & 26.5 & 29.0 & 19.9 & 29.2 & 23.8 & 7.2 & 17.5 \\
\hline
\end{tabular}

B. Total percentage change in binding following ATN lesions ${ }^{b}$

$$
\begin{array}{llllllll}
+9.9 & -53.0 & -104.2 & -73.9 & -125.1 & -108.9 & -18.1 & -84.9
\end{array}
$$

\footnotetext{
a Percentage distribution of specific $P L$ binding is presented for each layer in normal cortex. All other laminar distribution were calculated by subtracting these $\mathrm{PZ}$ percentages from the laminar pattern determined for each ligand. Where $\mathrm{PZ}$ is used as an unlabeled blocker, its concentration is $10^{-7} \mathrm{M}$ with PrBCM and $5 \times 10^{-8} \mathrm{M}$ with OXO and QNB. The absolute value of these percentage variations from the $\mathrm{PZ}$ distribution were summed to determine the index of heterogeneity. Each group represents a mean for 4-7 animals processed at the same time.

${ }^{n}$ Mean values of specific binding were calculated for 4-7 animals in normal and ATN-ablated hemispheres. Percentage changes in binding were determined for layers I-IV and summed.
} 


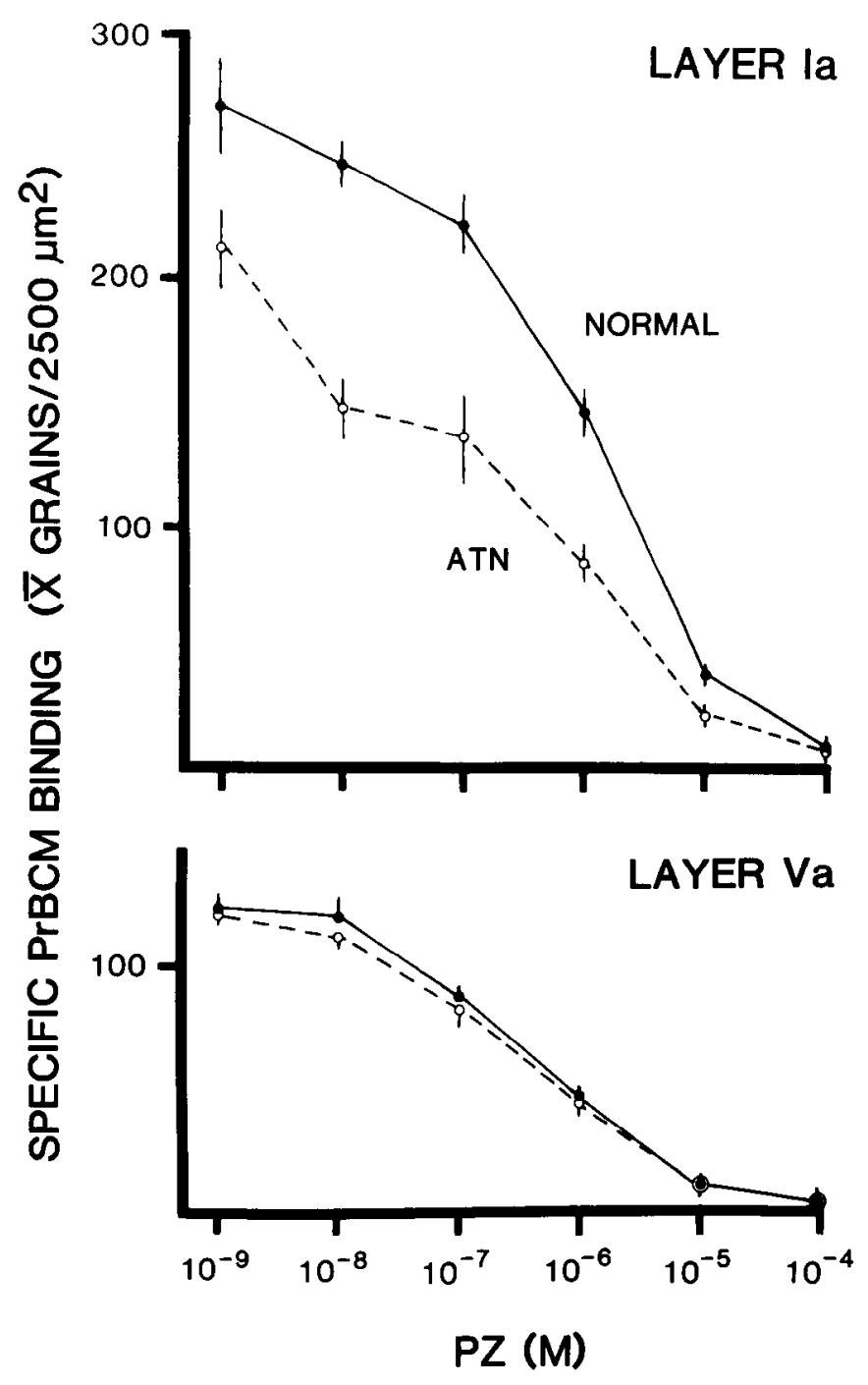

Figure 2. Competition curves for PZ block of specific ${ }^{3} \mathrm{H}-\mathrm{PrBCM}$ binding. Values were determined in unoperated (NORMAL, solid lines) and thalamic-ablated ( $A T N$, dashed lines) hemispheres. In general, $10^{-7}$ or $10^{-8} \mathrm{M} \mathrm{PZ}$ uncovered the most pronounced lesion effects in layers that received the densest thalamic termination, such as layer Ia.

M unlabeled $\mathrm{PZ}$ produced higher indices than did high or low concentrations of $\mathrm{OXO}$ alone. Fourth, the highest indices were those in which $5 \times 10^{-8} \mathrm{M}$ unlabeled $\mathrm{PZ}$ was used to block either OXO or PrBCM binding. Finally, although QNB had a low index, its index was improved proportionately more with $\mathrm{PZ}$ than were those for other ligands.

\section{Muscarinic receptor subtype on axons of thalamic neurons}

Anterior thalamic ablations. The ATN project mainly to layer Ia of area $29 \mathrm{c}$; there is less termination in layers Ib and IV and least in layers Ic-III. No termination occurs in layers $\mathrm{V}$ or VI (Vogt ct al., 1981). Lesions of the ATN failed to produce any significant alterations in $\mathrm{PZ}$ binding. The same lesions, however, consistently reduced PrBCM hinding in layer Ia, while layer IV reductions were not always significant among the different experiments. Blocking the $\mathrm{M}_{1}$ component of PrBCM binding by coincubation in various concentrations of unlabeled $P Z$ uncovered the greatest ablation effects in layer Ia at $10^{-8}-10^{-7} \mathrm{M} \mathrm{PZ}$ (Fig. 2). There were no changes in nonspecific binding following
ATN lesions. In layer Ia of unoperated hemispheres, for example, nonspecific binding was $14.2 \pm 0.37$ grains $/ 2500 \mu \mathrm{m}^{2}$ and $13.7 \pm 0.45$ in layer Ia of operated hemispheres. Note that effective concentrations to block the $M_{1}$ component of QNB and $\mathrm{N}$-methylscopolamine binding (Luthin and Wolfe, 1984; Palacios et al., 1986) and the high-affinity component of OXO binding (Bevan, 1984) would be in the $10^{-8}-10^{-7} \mathrm{M}$ range of PZ. Additionally, $\mathrm{IC}_{50}$ values were shifted after ATN lesions in superficial but not athalamic deep layers. Thus, $\mathrm{IC}_{50}$ values in normal layers $\mathrm{Ia}, \mathrm{Ib}$, and Ic were $1.3 \times 10^{-6}, 7 \times 10^{-7}$, and $2.1 \times 10^{-7} \mathrm{M}$, respectively. After ATN lesions they were $3.9 \times$ $10^{-7}$ and $1.6 \times 10^{-7} \mathrm{M}$ for layers $\mathrm{Ia}$ and $\mathrm{Ib}$, respectively, with no shift in layer Ic and only a small shift in layer IV. As can be seen in Figure 2, there were no lesion-induced alterations in layer V. It is interesting to note that, in addition to having a stable postlesion $\mathrm{IC}_{50}$, layer Ic had the greatest proportion of all PZ binding (Fig. 1).

Figure 3 compares PrBCM and $\mathrm{OXO}$ binding with and without unlabeled PZ. Only one significant reduction after ATN ablations in PrBCM binding occurred in layer Ia without PZ; however, with PZ significant changes in PrBCM binding occurred in 4 layers. Although significant alterations in $\mathrm{OXO}$ binding occurred in layers Ia and IV, there was also a significant reduction in layer $\mathrm{Ib}$ following the $\mathrm{PZ}$ block.

Ablations of the ATN never reduced OXO, OXO/PZ, Pr$\mathrm{BCM}$, or PrBCM/PZ binding to homogeneity, i.e., peaks in specific binding in layers Ia and IV remained postoperatively. In contrast, $\mathrm{QNB} / \mathrm{PZ}$ binding was reduced to homogeneity by ATN ablations. In area $29 \mathrm{c}$ of unablated hemispheres $(n=4)$, specific QNB/PZ binding was as follows: Ia, $181 \pm 10$; Ib, $102 \pm$ 8 ; Ic, $118 \pm 5$; II-III, $143 \pm 11$; IV, $153 \pm 9$; Va, $122 \pm 10$; $\mathrm{Vb}, 120 \pm 13$; and VI, $79 \pm 4$. In the ATN-ablated hemispheres binding was as follows: Ia, $119 \pm 15$; Ib, $93 \pm 8$; Ic, $106 \pm 10$; II-III, $123 \pm 14 ;$ IV , $126 \pm 12 ;$ Va, $121+11 ; \mathrm{Vb}, 115 \pm 15$; and VI, $83 \pm 13$.

Total percentage changes following ATN lesions. Since the ATN terminate in superficial layers and this was where significant reductions in binding occurred following ATN lesions, changes in binding in layers I-IV following ATN ablations were summed for each ligand. This produced a measure of the efficiency by which a ligand recognized $\mathrm{M}_{2}$ sites associated with ATN axons. The total percentage reductions in $\mathrm{OXO} / \mathrm{PZ}$ binding in layers I-IV was 125.1 , and this value was greater than that for all other ligands tested [Table 1(B)]. The rank order was as follows: $\mathrm{OXO} / \mathrm{PZ}>\mathrm{OXO}(0.1 \mathrm{nM}) \approx \mathrm{PrBCM} / \mathrm{PZ}>\mathrm{QNB} /$ $\mathrm{PZ}>\mathrm{PrBCM}>\mathrm{QNB}>\mathrm{PZ}$.

Based on both the index of heterogeneity and total percentage reductions in binding following $\mathrm{ATN}$ ablations, $\mathrm{OXO} / \mathrm{PZ}$ and PrBCM/PZ were the most efficient ligands for $\mathrm{M}_{2}$ sites.

\section{Localization of dendritic $M_{1}$ receptors}

Full-depth neurotoxin lesions. Ibotenic acid lesions were made in which there was relatively complete destruction of the full depth of parts of area 29c. In 8 such cases, specific $\mathrm{PZ}$ binding throughout area $29 \mathrm{c}$ was uniformly reduced by an average of $69 \%$ (Fig. 4). In the same cases there was an overall reduction in PrBCM binding of $56 \%$.

Laminar neurotoxin lesions. Full-depth neurotoxin lesions remove all neuronal somata and their associated dendrites and axons. In a number of instances, however, injections were either small and restricted to 1 or 2 layers or large, with spread into the contralateral hemisphere and subsequent destruction mainly 


\section{$\operatorname{PrBCM}$}
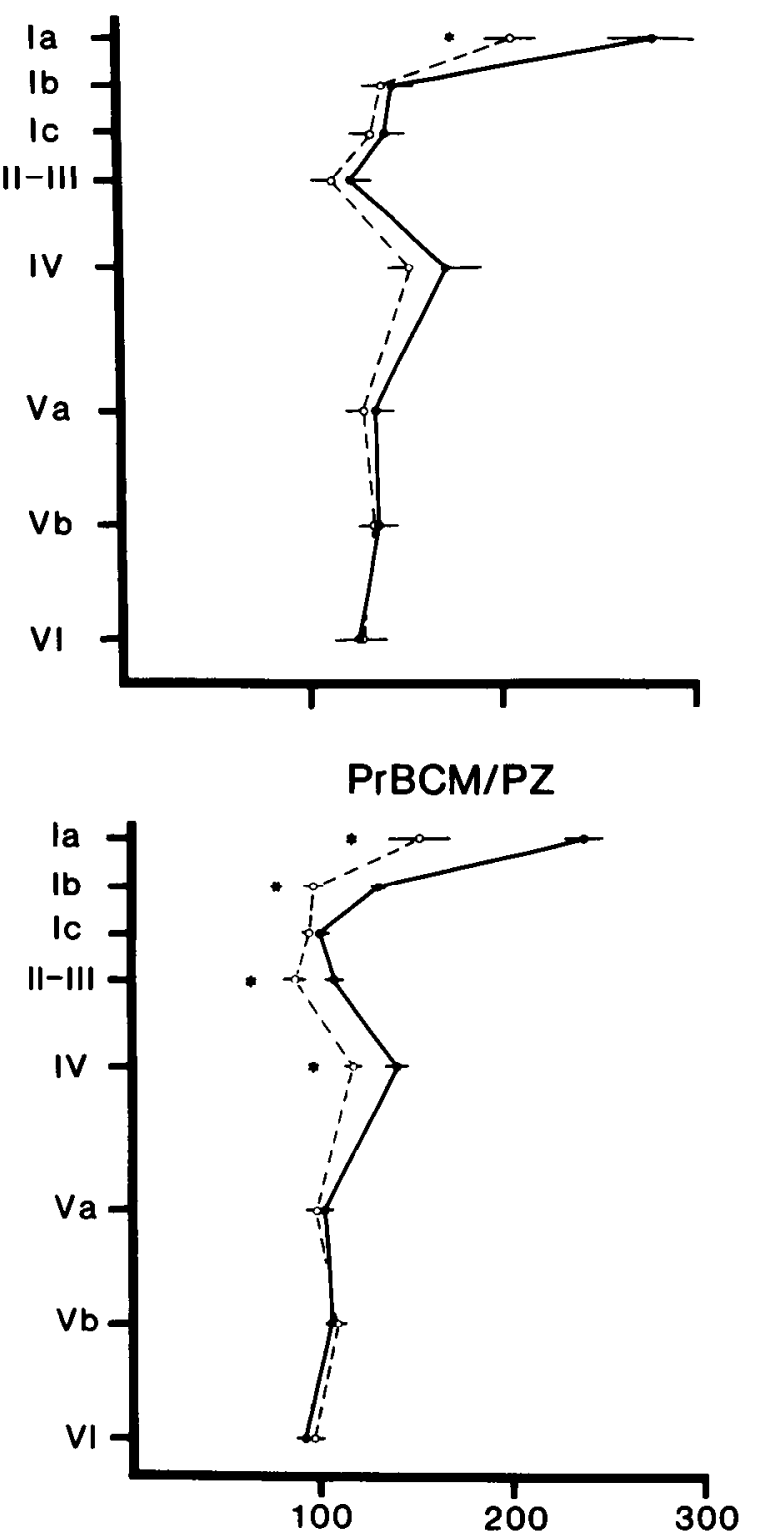
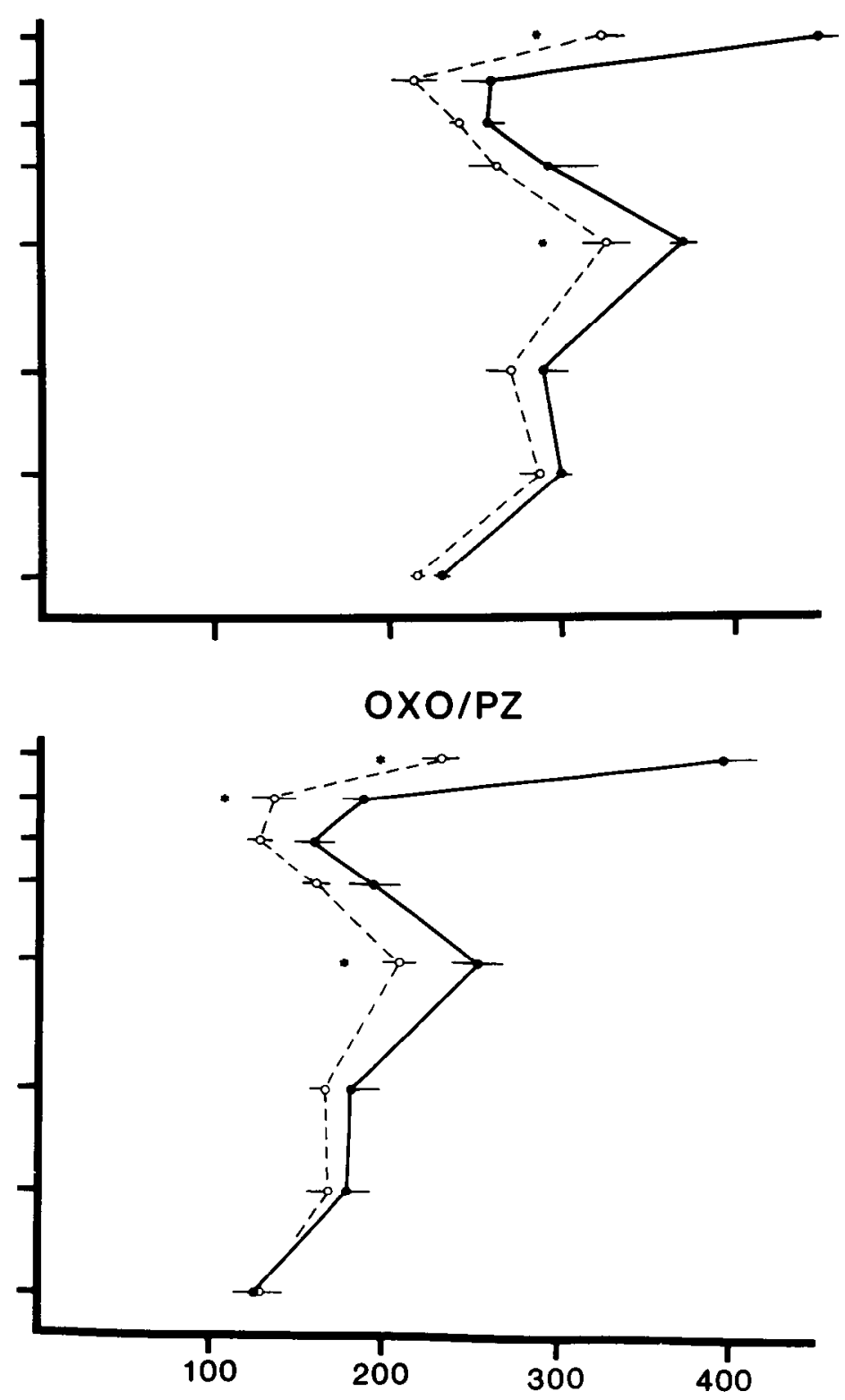

\section{SPECIFIC BINDING ( $\bar{X}$ GRAINS/2500 $\mu \mathrm{m}^{2}$ )}

Figure 3. Laminar profiles of specific PrBCM and OXO-binding alone or with a PZ block. Solid lines are for normal hemispheres and dashed lines for ATN-ablated hemispheres. Statistically significant reductions in binding (asterisks) consistently occurred only in layer Ia, with changes in layer IV reaching significance in some but not all groups of animals. A PZ block $\left(10^{-7} \mathrm{M}\right.$ with $\mathrm{PrBCM}$ and $5 \times 10^{-8} \mathrm{M}$ with OXO) uncovered consistent and significant losses in layers $\mathrm{Ia}, \mathrm{Ib}$, and IV.

of layers II-IV. These lesions were particularly valuable because alterations in binding could be evaluated in terms of the apical dendritic trees of pyramidal neurons. A photograph of one such lesion and its associated PZ binding is shown in Figure 5. The generally high level of glial cells throughout ablated cortex suggested that perikaryal and dendritic loss had occurred throughout layers I-IV, as well as degeneration of the efferent axons of layers II-IV pyramidal cells that exit from the cortex via layers $\mathrm{V}$ and VI.

Figure 6 shows the PZ binding for 3 laminar lesions (i.e., neurons in layers II-IV were primarily destroyed) and 3 normal, unablated cases processed at the same time and in the same manner. Specific PZ binding was reduced most dramatically in layers I-III, with the greatest loss (78\%) occurring in layer Ia. A smaller, though still significant loss of $38 \%$ occurred in layer IV. The reduction in layer $\mathrm{Va}$ was not statistically significant, and there were no differences in layers $\mathrm{Vb}$ or VI. In 2 other cases a lesion was made in layers $\mathrm{Vb}$ and $\mathrm{VI}$. In these cases PZ binding was reduced in all layers superficial to the lesion, including $10-20 \%$ in layer $\mathrm{I}$.

\section{Localization of dendritic $M_{2}$ receptors}

Thalamic lesions never abolished the laminar heterogeneity in PrBCM, PrBCM/PZ, OXO, or OXO/PZ binding; only binding 
Figure 4. Laminar profile of reductions in specific $\mathrm{PZ}$ binding in area $29 \mathrm{c}$ following ibotenic acid injections (mean $\pm \mathrm{SE}$, dashed lines) compared with normal, unoperated controls (solid lines).

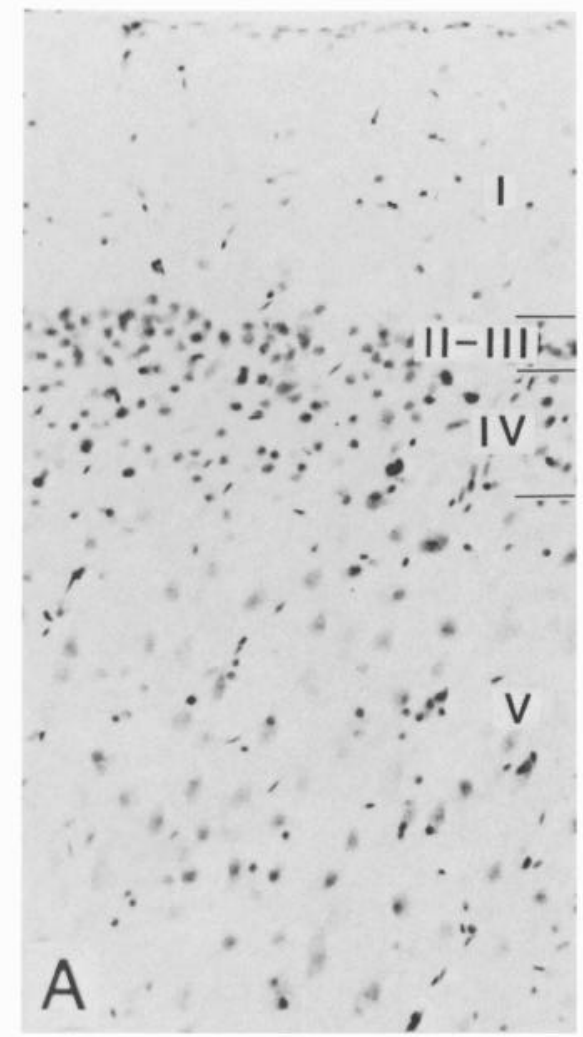

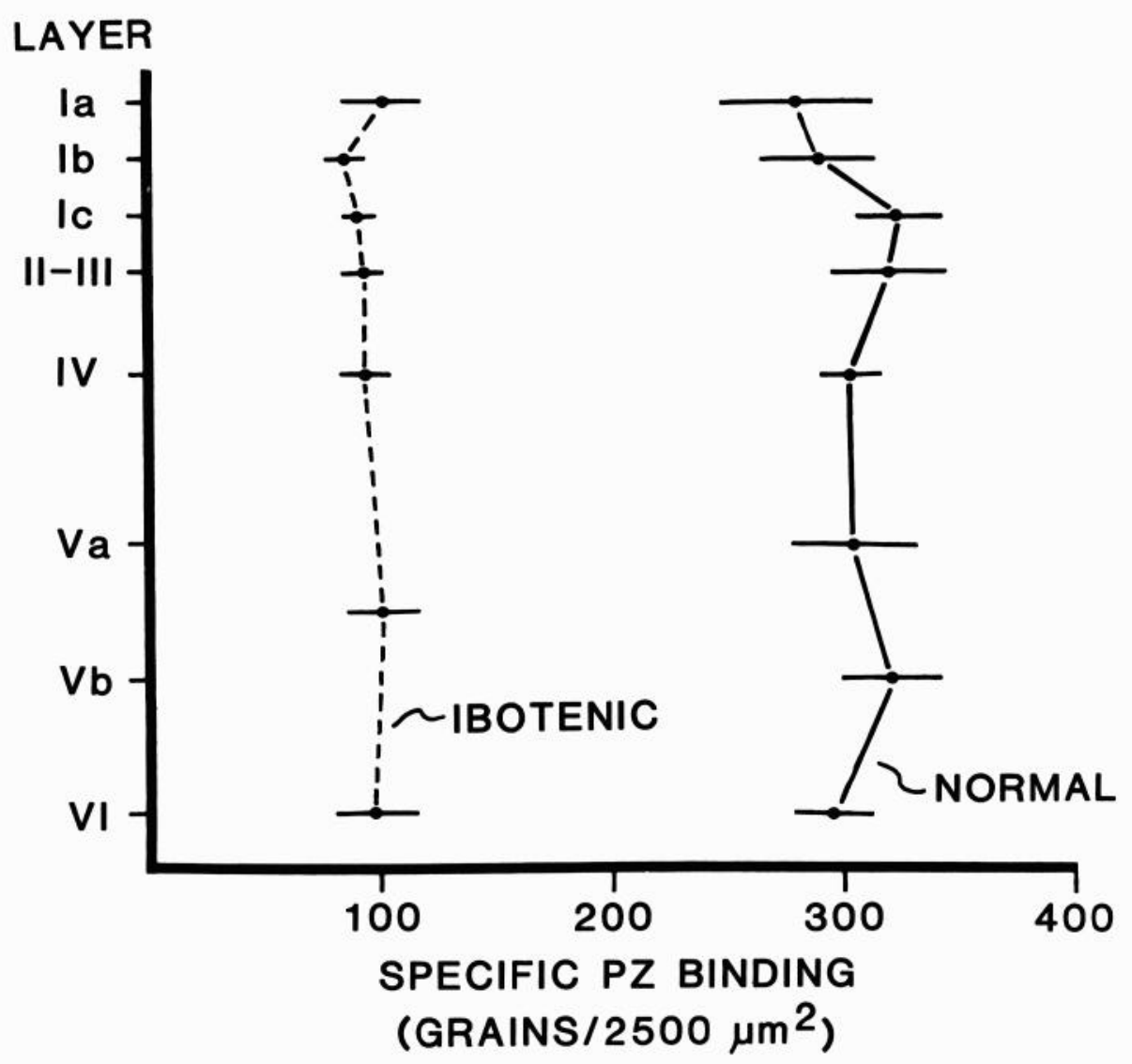
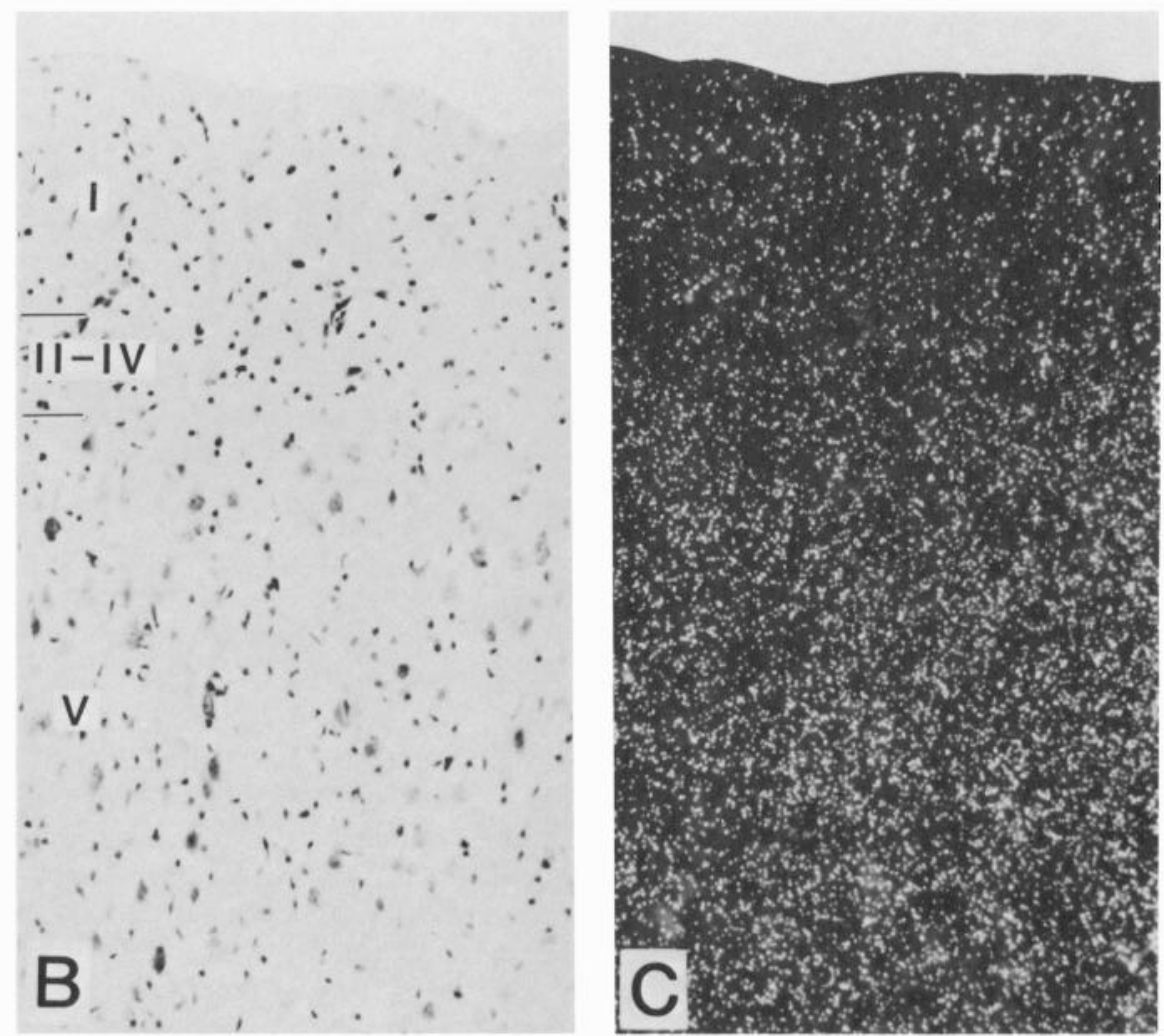

Figure 5. Neurotoxin ablation of the granular layers II-IV of area $29 \mathrm{c}$. $A$, Normal cryomicrotome section of area $29 \mathrm{c}$. B, Ibotenic acid ablation of area $29 \mathrm{c}$. Cortical shrinkage and gliosis was associated with these lesions. Gliosis in superficial layers I-IV was due to dendritic and perikaryal degeneration and that in deeper layers was associated with degeneration of efferent axons. $C$, $\mathrm{PZ}$ binding in the same case as in $B$. There was a clear reduction of binding in superficial layers, but it was normal in deep layers. This is one of 3 cases presented in Figure 6. 


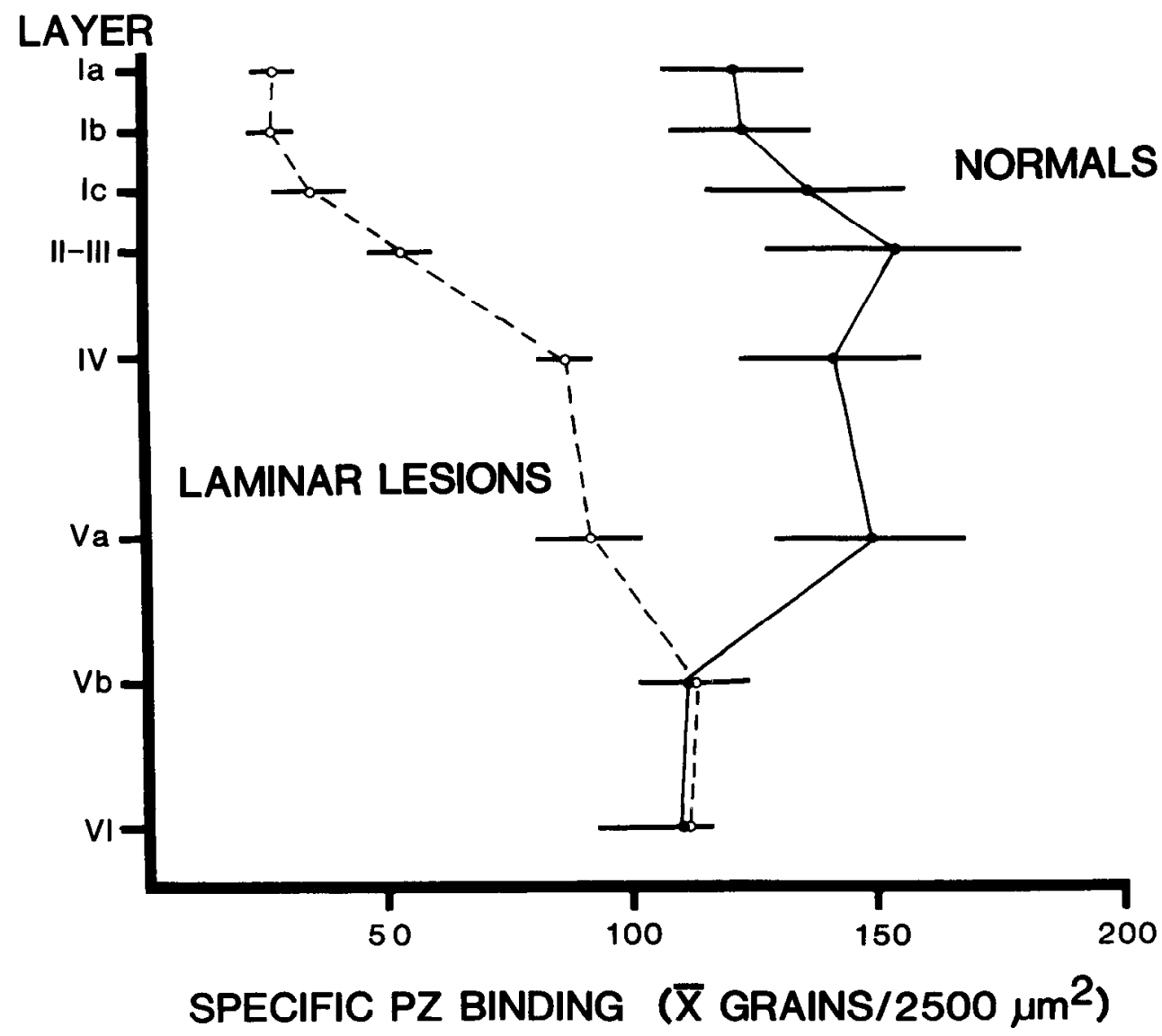

Figure 6. Reductions in $\mathrm{PZ}$ binding following 3 neurotoxin lesions of layers II-IV compared with normal PZ binding in 3 cases prepared in the same experiment. The reduction in layer $\mathrm{Va}$ binding was not statistically significant. of QNB/PZ was reduced to homogeneity following ATN ablations (see above). Peak layer Ia binding was usually reduced by $40-50 \%$ for the former ligands. Although incomplete ATN lesions could account for some variation, complete undercut lesions also failed to abolish the layer Ia peak in PrBCM binding (Vogt, 1984). In addition, ibotenic acid lesions always reduced peak binding of PrBCM and $\mathrm{OXO} / \mathrm{PZ}$ in layers Ia and IV by about $50 \%$. One explanation for persistent heterogeneity in binding following these lesions is that $\mathbf{M}_{2}$ sites in layers Ia and IV are on both axons and dendrites.

Full-depth ibotenic acid ablations reduced PrBCM binding in layers Ia and IV by 51 and $49 \%$, respectively (Fig. 7). The remaining peaks reflected binding to intact ATN axons because, following combined cortical and ATN ablations, PrBCM binding was reduced to homogeneity with losses of 91 and $82 \%$ in layers Ia and IV, respectively. In 3 cases assayed with $\mathrm{OXO} /$ $\mathrm{PZ}$, cortical ibotenic acid injections reduced layer Ia binding by $75 \%$ and, when combined with ATN lesions, it was reduced to background levels.

\section{Discussion}

Three issues have been raised in the present study: (1) Structural indices were developed to rank order ligand potency for cortical $\mathrm{M}_{2}$ receptors; (2) the muscarinic receptor subtype associated with thalamic axons was assessed; and (3) localization of $M_{1}$ and $\mathrm{M}_{2}$ receptors to the dendrites of cortical neurons was accomplished with laminar and combined cortical and thalamic lesion techniques.

\section{Ligand selection for $M_{2}$ sites}

Pirenzepine is frequently used to identify $M_{1}$ muscarinic receptors in the CNS (Hammer et al., 1980; Watson et al., 1983; Luthin and Wolfe, 1984; Wamsley et al., 1984; Meyer and Otero, 1985; Spencer et al., 1986). In the present study, summed deviations from the homogeneous laminar pattern of PZ binding were used as one means of identifying ligands that bound most efficiently to $M_{2}$ sites. A second structural criterion for an $M_{2}$ selective ligand was the sum of all percentage changes in binding in layers I-IV following ATN lesions. Pharmacological studies usually determine the order of potency for a series of ligands with a measure of affinity. Drawbacks to this approach are the large amount of tissue required for each determination and the limited topographic and cell process resolution. The structural criteria developed here require the use of a range of most likely effective protocols followed by sublaminar assessment of normal and postablation binding to determine the potency order for a group of ligands. Although this approach is costly and timeconsuming, it provides an independent measure of pharmacological specificity that can be directly linked to structural entities. The 2 structural indices of $\mathrm{M}_{2}$ binding indicated that, of the ligands tested, $\mathrm{OXO} / \mathrm{PZ}$ and $\mathrm{PrBCM} / \mathrm{PZ}$ were preferable for characterizing the distribution of $\mathrm{M}_{2}$ sites.

QNB was not as effective at labeling heterogeneously positioned $M_{2}$ sites as were other multiple site ligands, and this difference may serve as a basis for further subtyping $M_{2}$ sites. Thus, the layer Ia peak for QNB was not ncarly as pronounced 
Figure 7. Influence of ibotenic acid lesions in cortex and thalamus on $\operatorname{PrBCM}$ binding. Injections into cortex only ( 29 , $n=5$, dashed line) reduced PrBCM binding but did not abolish the peaks in layers Ia and IV. Combined cortical and thalamic lesions ( $29 \&$ ATN, $n=$ 3 , dotted line) reduced PrBCM binding to homogeneity.

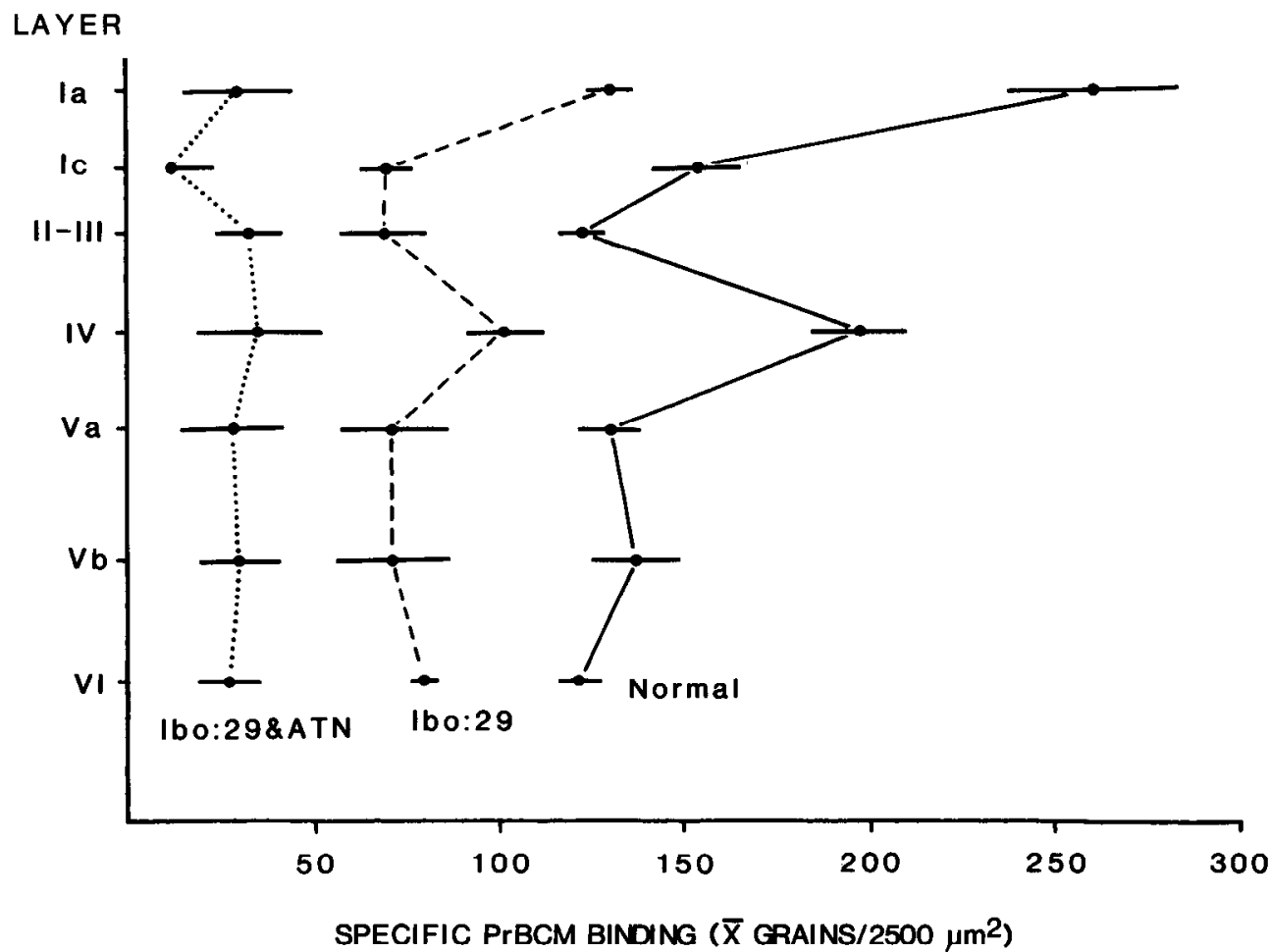

as that for PrBCM or OXO and a larger proportion of QNB binding was to $M_{1}$ sites, since $P Z$ produced the greatest overall improvement in the QNB index of heterogeneity. Since ATN lesions reduced $\mathrm{QNB} / \mathrm{PZ}$ binding to homogeneity, it is proposed that QNB failed to recognize dendritic $\mathrm{M}_{2}$ sites. The literature raises 2 issues that are relevant to these findings. First, agonist and antagonist competition studies of QNB binding, as well as multiple sitc binding in the presence of $\mathrm{Mg}^{+2}$, suggest that QNB differentiates between receptors (Ehlert et al., 1981; Burgisser et al., 1982; Lee and El-Fakahany, 1985), as may be the case in the present study. Second, it appears that the distributions of QNB and PZ binding parallel each other in cortical areas that do not receive ATN afferents (Watson et al., 1985). These investigators suggested that $\mathrm{QNB}$ and $\mathrm{PZ}$ labeling may be postsynaptic.

In conclusion, it has been proposed that $\mathrm{M}_{2}$ sites are heterogeneous based on studies of heart muscle and cerebral cortex (Giachetti and Mittman, 1985; Giraldo et al., 1987). If it is true that $\mathrm{M}_{2}$ sites are located on dendrites as well as axons in the cerebral cortex, it is possible that their binding properties can be differentiated pharmacologically.

\section{Localization of axonal $M_{2}$ sites}

Biochemical studies support the notion that muscarinic receptors are on axon terminals and that many are of the $\mathrm{M}_{2}$ subtype (Ganguly and Das, 1979; Nordstrom and Bartfai, 1980; Fisher et al., 1981; Zarbin et al., 1982; Raiteri et al., 1984; Mash et al., 1985). The following observations suggest that thalamic afferents to cortex have primarily $\mathrm{M}_{2}$ receptors. First, layer Ia normally has peak $\mathrm{PrBCM} / \mathrm{PZ}$ and $\mathrm{OXO} / \mathrm{PZ}$ binding but lowest $\mathrm{PZ}$ binding, suggesting that the $\mathrm{M}_{2}$ component of PrBCM and OXO binding accounts for many of the layer Ia sites, a layer that receives most ATN input (Vogt et al., 1981). Second, ATN ablation greatly reduces $\mathrm{PrBCM} / \mathrm{PZ}$ and $\mathrm{OXO} / \mathrm{PZ}$ binding in layers Ia, Ib, and IV but has no effect on PZ binding in any layers. This laminar pattern in altered binding also closely approximates the structural distribution of ATN cortical afferents. Third, competition studies indicate that layers which do not receive thalamic input like layer $\mathrm{V}$ are dominated by highaffinity binding, while layer Ia, which receives most of this input, has a larger component of low-affinity sites. Layer $\mathrm{V} \mathrm{IC}_{50}$ values are similar to those reported for cortical homogenates (Hammer et al., 1980; Watson et al., 1983; Luthin and Wolfc, 1984). Fourth, ATN lesions uncover high-affinity PZ sites and shift $\mathrm{IC}_{50}$ values to lower concentrations.

$M_{2}$ receptors on ATN axons are probably muscarinic heteroreceptors because ATN input is noncholinergic, i.e., does not have choline acetyltransferase activity (Kimura et al., 1981; Armstrong et al., 1983). It is unclear as to how these receptors modulate transmitter release from axon terminals of ATN neurons. ACh has been shown to inhibit release of noncholinergic excitatory transmitters in the hippocampus (Hounsgaard, 1978; Valentino and Dingledine, 1981; Rovira et al., 1983). Since ATN afferents to cingulate cortex are probably excitatory (Finch et al., 1984), ACh might inhibit the activity of ATN terminals in cingulate cortex. However, since muscarinic heteroreceptors on dopaminergic terminals in the striatum enhance dopamine release, it is also possible, though less likely, that ACh enhances transmitter release from ATN terminals.

\section{Localization of dendritic $M_{1}$ and $M_{2}$ sites}

Although an autoradiographic study of PZ and QNB binding to sections of neocortex indicated that the laminar distribution of each was essentially homogeneous in neocortex and did not differ in retrosplenial cortex (Wamsley et al., 1984), earlier and more recent autoradiographic studies have suggested that there is a differential distribution of high- and low-affinity sites in neocortex (Wamsley et al., 1980; Spencer et al., 1986). The present study of cingulate cortex shows that the relative distribution of cortical PZ sites is almost a reverse image of PrBCM/ 
$\mathrm{PZ}$ and $\mathrm{OXO} / \mathrm{PZ}$ binding and provides direct experimental evidence for localization of these sites to pyramidal cell apical dendrites.

The conclusion that cortical neurons have $M_{1}$ receptors is supported by 3 observations. First, in the present study there was an almost $70 \%$ loss of specific PZ binding following neurotoxin lcsions. Sccond, ACh-cvoked, slow depolarization in pyramidal neurons is PZ sensitive (McCormick and Prince, 1985, 1986). Third, high-resolution autoradiographic localization of PZ-sensitive sites to dendrites and somata has been made with dissociated cortical neurons (Vogt et al., 1987).

Alterations in the laminar profile of PrBCM binding in area $29 \mathrm{c}$ following a number of different surgical procedures serves as the basis for localizing $M_{1}$ and $M_{2}$ receptors to the apical dendrites of pyramidal neurons. Thus, the 2 peaks in PrBCM/ $\mathrm{PZ}$ and $\mathrm{OXO} / \mathrm{PZ}$ binding in laminae Ia and IV remain after ATN lesions, PrBCM peak binding persists after undercut lesions (Vogt, 1984), and cortical ibotenic acid lesions reduce, but do not abolish, peaks in PrBCM and OXO/PZ binding, although binding in all layers is reduced by all lesions except the undercut procedure. A combination of cortical and thalamic lesions abolishes the 2 peaks, indicating that both cortical neurons and afferents contribute to the $\mathrm{M}_{2}$ component of classical antagonist binding. With which cortical cells is the layer Ia peak associated? Only small and fusiform pyramids in layers II-IV have apical tufts which arborize preferentially in layer Ia (Vogt and Peters, 1981; Vogt, 1985). This contrasts with the even distribution throughout layer I of multipolar, bipolar, and extraverted pyramidal cell dendrites and apical tufts of layers $V$ and VI pyramidal neurons. Removal of the dendrites of neurons in layers II-IV or V and VI with discrete neurotoxin lesions produced a $10-80 \%$ reduction in PZ binding in layers I-IV. A nonaxonal location for $M_{2}$ sites was also suggested by McCormick and Prince $(1985,1986)$, who observed ACh-evoked, non-PZ-sensitive, rapid depolarizations in nonpyramidal neurons. The observations of the present study cannot discount, however, the presence of presynaptic $\mathbf{M}_{2}$ receptors on the ascending axons of intrinsic cells nor the possibility that there is an overlap of ligand binding to a population of low-affinity $M_{1}$ sites in layers Ia and IV. In conclusion, since removal of cells in layers II-VI by ibotenic acid lesions reduces peak binding of PrBCM in layer Ia, it is suggested that the apical tufts of both small-fusiform and large pyramids have muscarinic receptors and that those of small-fusiform pyramids contribute to the laminar heterogeneity in PrBCM and OXO binding.

In conclusion, intrinsic and deafferentation ablation procedures can be used with a high degree of resolution to localize varieties of muscarinic receptor subtypes in the cerebral cortex. The differential localization of muscarinic receptors in cingulate cortex described here provides a model assay system for evaluating receptor and structural specificity of muscarinic binding as new ligands become available. It is also reasonable to expect that the structurally based indices of ligand potency will be extended for use in studying structure-receptor relationships in other neurotransmitter systems.

\section{References}

Andree, T. H., Z. Gottesfeld, J. F. DeFrance, R. W. Sikes, and S. J. Enna (1983) Evidence for cholinergic muscarinic receptors on mediodorsal thalamic projections to the anterior cingulate cortex. Neurosci. Lett. 40: 99-103.

Armstrong, D. M., C. B. Saper, A. I. Levey, B. H. Wainer, and R. D.
Terry (1983) Distribution of cholinergic neurons in rat brain: Demonstrated by the immunohistochemical localization of choline acetyltransferase. J. Comp. Neurol. 216: 53-68.

Bevan, P. (1984) [ $\left.{ }^{3} \mathrm{H}\right]$ Oxotremorine-M binding to membranes prepared from rat brain and heart: Evidence for subtypes of muscarinic receptors. Eur. J. Pharmacol. 101: 101-110.

Birdsall, N. J. M., A. S. V. Burgen, and E. C. Hulme (1978) The binding of agonists to brain muscarinic receptors. Mol. Pharmacol. 14: 723-736.

Briggs, R. S., P. Redgrave, and S. R. Nahorski (1981) Effect of kainic acid lesions on muscarinic agonist receptor subtypes in rat striatum. Brain Res. 206: 451-456.

Burgisser, E., A. De Lean, and R. J. Lefkowitz (1982) Reciprocal modulation of agonist and antagonist binding to muscarinic cholinergic receptor by guanine nucleotide. Proc. Natl. Acad. Sci. USA 79. 1732-1736.

De Belleroche, J., B. C. Kilpatrick, N. J. M. Birdsall, and E. C. Hulme (1982) Presynaptic muscarinic receptors on dopaminergic terminals in nucleus accumbens. Brain Res. 234: 327-337.

Ehlert, F. J., W. R. Roeske, and H. I. Yamamura (1981) Striatal muscarinic receptors: Regulation by dopaminergic agonists. Life Sci. 28: 2441-2448.

Finch, D. M., E. L. Derian, and T. L. Babb (1984) Excitatory projection of the rat subicular complex to the cingulate cortex and synaptic integration with thalamic afferents. Brain Res. 301: 25-37.

Fisher, S. K., K. A. Frey, and B. W. Agranoff (1981) Loss of muscarinic receptors and of stimulated phospholipid labeling in ibotenate-treated hippocampus. J. Neurosci. 1: 1407-1413.

Ganguly, D. K., and M. Das (1979) Effects of oxotremorine demonstrate presynaptic muscarinic and dopaminergic receptors on motor terminals. Nature 278: 645-646.

Giachetti, A., and U. Mittmann (1985) Cardioselective muscarinic antagonists. Symposium presented by the American Society for Pharmacology and Experimental Therapeutics. Boston, MA.

Giraldo, E., R. Hammer, and H. Ladinsky (1987) Distribution of muscarinic receptor subtypes in rat brain as determined in binding studies with AF-DX 116 and pirenzepine. Life Sci. 40: 833-840.

Hammer, R., and A. Giachetti (1982) Muscarinic receptor subtypes: $M_{1}$ and $M_{2}$ biochemical and functional characterization. Life Sci. 31: 2991-2998.

Hammer, R., C. P. Berrie, N. J. M. Birdsall, A. S. V. Burgen, and E. C. Hulme (1980) Pirenzepine distinguishes between different subclasses of muscarinic receptors. Nature 283: 90-92.

Hattori, T., and H. C. Fibiger (1982) On the use of lesions of afferents to localize neurotransmitter receptor sites in the striatum. Brain Res. 238: $245-250$.

Hounsgaard, J. (1978) Presynaptic inhibitory action of acetylcholine in area CA1 of the hippocampus. Exp. Neurol. 62: 787-797.

James, W. L., and W. L. Klein (1982) Autoradiography of dendritic acetylcholine receptors: $A$ method for study of isolated neurons of the adult central nervous system in the turtle. Neurosci. Lett. 32: 510.

Kamiya, H.-O., A. Rotter, and D. M. Jacobowitz (1981) Muscarinic receptor binding following cholinergic nerve lesions of the cingulate cortex and hippocampus of the rat. Brain Res. 209: 432-439.

Kimura, II., P. L. McGeer, J. H. Peng, and E. G. McGeer (1981) The central cholinergic system studied by choline acetyltransferase immunohistochemistry in the cat. J. Comp. Neurol. 200: 151-201.

Lee, J.-H., and E. E. El-Fakahany (1985) Heterogeneity of binding of muscarinic receptor antagonists in rat brain homogenates. J. Pharmacol. Exp. Ther. 233: 707-714.

Luthin, G. R., and B. B. Wolfe (1984) Comparison of ${ }^{3} \mathrm{H}$-pirenzepine and ${ }^{3} \mathrm{H}$-quinuclidinyl benzilate binding to muscarinic cholinergic receptors in rat brain. J. Pharmacol. Exp. Ther. 228: 648-655.

Mash, D. C., D. D. Flynn, and L. T. Potter (1985) Loss of M2 muscarinic receptors in the cerebral cortex in Alzheimer's disease and experimental cholinergic denervation. Science 228: 1115-1117.

McCormick, D. A., and D. A. Prince (1985) Two types of muscarinic response to acetylcholine in mammalian cortical neurons. Proc. Natl. Acad. Sci. USA 82: 6344-6348.

McCormick, D. A., and D. A. Prince (1986) Pirenzepine discriminates among ionic responses to acetylcholine in guinea-pig cerebral cortex and reticular nucleus of thalamus. Trends Pharmacol. Sci. (Suppl.) 7: 72-77.

Meyer, E. M., and D. H. Otero (1985) Pharmacological and ionic 
characterizations of the muscarinic receptors modulating ${ }^{3} \mathrm{H}$-acetylcholine release from rat cortical synaptosomes. J. Neurosci. 5: 12021207.

Nordstrom, O., and T. Bartfai (1980) Muscarinic autoreceptor regulates acetylcholine release in rat hippocampus: In vitro evidence. Acta Physiol. 108: 347-353.

Potter, L. T., D. D. Flynn, H. E. Hanchett, D. L. Kalinoski, J. LubarNarod, and D. C. Mash (1984) Independent $M_{1}$ and $M_{2}$ receptors: Ligands, autoradiography and functions. Trends Pharmacol. Sci. (Suppl.) 5: 22-30.

Raiteri, M., R. Leardi, and M. Marchi (1984) Heterogeneity of presynaptic muscarinic receptors regulating neurotransmitter release in the rat brain. J. Pharmacol. Exp. Ther. 228: 209-214.

Rotter, A., N. J. M. Birdsall, A. S. V. Burgen, P. M. Field, E. C. Hulme, and G. Raisman (1979) Muscarinic receptors in the central nervous system of the rat. I. Technique for autoradiographic localization of the binding of ${ }^{3} \mathrm{H}$-propylbenzilylcholine mustard and its distribution in the forebrain. Brain Res. Rev. 1: 141-165.

Rovira, C., Y. Ben-Ari, E. Cherubini, K. Krnjevic, and N. Ropert (1983) Pharmacology of the dendritic action of acetylcholine and further observations on the somatic disinhibition in the rat hippocampus in situ. Neuroscience 8: 97-106.

Schwarcz, R., T. Hökfelt, K. Fuxe, G. Jonsson, M. Goldstain, and L. Terenius (1979) Ibotenic acid-induced neuronal degeneration: A morphological and neurochemical study. Exp. Brain Res. 37: 199216

Spencer, D. G., E. Horvath, and J. Traber (1986) Direct autoradiographic determination of M1 and M2 muscarinic acetylcholine receptor distribution in the rat brain: Relation to cholinergic nuclei and projections. Brain Res. 380: 59-68.

Valentino, R. J., and R. Dingledine (1981) Presynaptic inhibitory effect of acetylcholine in the hippocampus. J. Neurosci. 1: 784-792.

Vogt, B. A. (1984) Afferent specific localization of muscarinic acetylcholine receptors in cingulate cortex. J. Neurosci. 4: 2191-2199.

Vogt, B. A. (1985) Cingulate cortex. In Cerebral Cortex, vol. 4, A. Peters and E. G. Jones, eds., pp. 89-149, Plenum Press, New York.

Vogt, B. A., and A. Peters (1981) Form and distribution of neurons in rat cingulate cortex: Areas 32, 24 and 29. J. Comp. Neurol. 195: 603-625, 200: 461 .
Vogt, B. A., D. L. Rosene, and A. Peters (1981) Synaptic termination of thalamic and callosal afferents in cingulate cortex of the rat. J. Comp. Neurol. 201: 265-283.

Vogt, B. A., E. Townes-Anderson, and D. L. Burns (1987) Dissociated cingulate cortical neurons: Morphology and muscarinic acetylcholine receptor binding properties. J. Neurosci. 7: 959-971.

Wamsley, J. K., M. A. Zarbin, N. J. M. Birdsall, and M. J. Kuhar (1980) Muscarinic cholinergic receptors: Autoradiographic localization of high and low affinity agonist binding sites. Brain Res. 200: 112.

Wamsley, J. K., D. R. Gehlert, W. R. Roeske, and H. I. Yamamura (1984) Muscarinic antagonist binding site heterogeneity as evidenced by autoradiography after direct labeling with ${ }^{3} \mathrm{H}-\mathrm{QNB}$ and ${ }^{3} \mathrm{H}$-pirenzepine. Life Sci. 34: 1395-1402.

Watson, M., Yamamura, and W. R. Roeske (1983) A unique regulatory profile and regional distribution of ${ }^{3} \mathrm{H}$-pirenzepine binding in the rat provide evidence for distinct $M_{1}$ and $M_{2}$ muscarinic receptor subtypes. Life Sci. 32: 3001-3011.

Watson, M., T. W. Vickroy, H. C. Fibiger, W. R. Roeske, and H. I. Yamamura (1985) Effects of bilateral ibotenate-induced lesions of the nucleus basalis magnocellularis upon selective cholinergic biochemical markers in the rat

Watson, M., W. R. Roeske, T. W. Vickroy, T. L. Smith, K. Akiyama, K. Gulya, S. P. Duckles, M. Serra, A. Adem, A. Nordberg, D. R. Gehlert, J. K. Wamsley, and H. I. Yamamura (1986) Biochemical and functional basis of putative muscarinic subtypes and its implications. Trends Pharmacol. Sci. (Suppl.) 7: 46-55.

Yamamura, II. I., J. K. Wamsley, P. Deshmukh, and W. R. Roeske (1983) Differential light microscopic autoradiographic localization of muscarinic cholinergic receptors in the brainstem and spinal cord of the rat using ${ }^{3} \mathrm{H}$-pirenzepine. Eur. J. Pharmacol. 91: 147-149.

Young, W. S., III, and M. J. Kuhar (1979) A new method for receptor autoradiography ${ }^{3} \mathrm{H}$-opioid receptor labeling in mounted tissue sections. Brain Res. 179: 255-270.

Zarbin, M. A., J. K. Wamsley, and M. J. Kuhar (1982) Axonal transport of muscarinic cholinergic receptors in rat vagus nerve: High and low affinity agonist receptors move in opposite directions and differ in nucleotide sensitivity. J. Neurosci. 2: 934-941. 